\title{
PEMBINAAN PARENTING BAGI ORANG TUA SISWA DI PAUD DAN TK ASSAABIQ SINGAPARNA KABUPATEN TASIKMALAYA
}

\author{
Cucu Arumsari ${ }^{1}$, Milah Nurkamilah ${ }^{2}$, Feida Noorlaila Ist'adah ${ }^{3}$ \\ ${ }^{123}$ Universitas Muhammadiyah Tasikmalaya \\ Email: cucu.arumsari@umtas.ac.id ${ }^{1}$, milah.nurkamilah@umtas.ac.id ${ }^{2}$, \\ feidanoor@gmail.com ${ }^{3}$
}

\begin{abstract}
ABSTRAK
Pendidikan Anak Usia Dini (PAUD) dan Taman Kanak-Kanak (TK) harus dapat memberikan layanan tidak hanya bagi anak di kelompok bermain saja, namun juga bagi orang tua sebagai mitra untuk berkolaborasi dalam proses pendidikan anak yang salah satunya melalui program parenting. TK dan PAUD Assaabiq terletak di desa Cipakat Kecamatan Singaparna belum melaksanakan kegiatan parenting bagi orang tua siswa secara berkala dan terprogram. Padahal, beberapa indikasi menunjukkan bahwa orang tua siswa belum memahami bagaimana fase perkembangan anak. Kemudian, masih banyak orang tua yang bersikap overprotektif sehingga perkembangan kemandirian anak tidak berkembang secara optimal. Selain itu, ketidakpahaman orang tua mengenai perkembangan kognitif anak, seringkali menuntut anak untuk dapat membaca, menulis dan berhitung secara instan serta membebankan tangggung jawab mengajar anak pada guru di sekolah. Oleh karena itu, parenting bagi orang tua siswa PAUD dan TK Assaabiq di Desa Cipakat Kecamatan Singaparna Kabupaten Tasikmalaya mengambil tema memahami fase tumbuh kembang anak. Adapun pembinaan yang diberikan yaitu 1) Pola asuh, materi ini diberikan dengan tujuan untuk memberikan pengetahuan bagi orang tua mengenai perkembangan anak usia 2-6 tahun secara psikologis. Setelah orang tua memahami fase tumbuh kembang anak dan mengetahui pola asuh yang tepat, diharapkan pola komunikasi antara orang tua dan anak akan terjalin dengan baik; 2) menumbuhkan kemandirian anak, materi ini bertujuan agar orang tua memahami dan mampu membedakan perlakuan pengasuhan mana yang dapat melatih kemandirian anak, serta pengasuhan mana yang dapat memanjakan anak sehingga kemandiriannya tidak berkembang optimal dan berpengaruh terhadap kemampuan anak menyelesaikan masalah, kemampuan sosial, dan religiusitas anak; dan 3) kemampuan berpikir logis dan simbolik pada anak, materi ini diberikan bertujuan upaya memberikan pengetahuan kepada orang tua mengenai perkembangan kognitif anak khususnya kemampuan logis dan simbolik, serta memberikan pemahaman kepada orang tua bahwa matematika dapat diajarkan sejak dini, melalui lingkungan alami anak dalam upaya meningkatkan kemampuan berpikir logis dan simbolik anak.
\end{abstract}

Kata kunci : parenting, orang tua, PAUD 


\begin{abstract}
Early Childhood Education (PAUD) and Kindergarten (Kindergarten) should be able to provide services not only for children in play groups, but also for parents as partners to collaborate in the child's education process through parenting program. Kindergarten and Early Childhood Assaabiq is located in the village of Cipakat Singaparna, has not conducted parenting activities for parents of students on a regular basis and programmed. In fact, some indications show that parents of students have not understood how the child's development phase. Then, there are still many parents who are overprotective so that the development of child self-sufficiency does not develop optimally. In addition, parents' lack of understanding of children's cognitive development often requires children to be able to read, write and count instantly and to charge teachers for teaching responsibilities at school. Therefore, parenting for parents of early childhood and kindergarten students Assaabiq in Cipakat Singaparna takes the theme of understanding the phases of child development. The coaching provided is 1) Parenting, this material is given with the aim to provide knowledge for parents about the development of children aged 2-6 years psychologically. After parents understand the child's growth and know the proper parenting pattern, it is expected that communication patterns between parents and children will be well established; 2) foster child selfreliance, this material aims to enable parents to understand and be able to distinguish which parenting treatment can train the child's independence, and which parenting can spoil the child so that his independence does not develop optimally and affect the child's ability to solve problems, social skills, and religiosity child; and 3) the ability to think logically and symbolically in children, this material aims to provide knowledge to parents about the cognitive development of children, especially logical and symbolic ability, and provide understanding to parents that mathematics can be taught from an early age, through the natural environment of children in an effort improve the logical and symbolic thinking of the child
\end{abstract}

Keywords : parenting, parents, early childhood education 


\section{PENDAHULUAN}

Penyelenggaraan pendidikan merupakan salah satu upaya yang ditempuh oleh pemerintah dalam membangun kualitas sumber daya manusia. Salah satu perhatian yang diberikan pemerintah dalam bidang pendidikan yaitu pada pendidikan untuk anak usia dini. Program Pendidikan Anak Usia Dini (PAUD), menitikberatkan pada peletakan dasar ke arah lingkup perkembangan yang meliputi aspek agama dan moral, fisik-motorik, kognitif, bahasa, sosio-emosional, dan seni (Permendikbud nomor 137, 2014: 5).

Orang tua memiliki posisi dan pengaruh yang penting dalam pendidikan anak usia dini di lingkungan rumah. Pendidikan yang dilakukan pada kelompok bermain harus berjalan seiring dengan pola pendidikan yang dilakukan orang tua di rumah agar stimulasi dasar untuk pengembangan sikap, perilaku, perasaan, kecerdasan, sosial dan fisik anak berkembang secara optimal. Dengan demikian, PAUD dan TK harus dapat memberikan layanan tidak hanya bagi anak di kelompok bermain saja, namun juga bagi orang tua sebagai mitra untuk berkolaborasi dalam proses pendidikan anak. Kolaborasi yang dilakukan oleh kelompok bermain dengan orang tua, keluarga, dan komunitas merupakan kunci yang esensial dalam proses pendidikan anak usia dini, karena anak mulai dan terus belajar dalam konteks keluarga (Morrison, 2004: 14).

Namun, berdasarkan hasil observasi menunjukkan bahwa hambatan dalam pendidikan di PAUD dan TK justru salah satunya datang dari orang tua. Hal ini didukung berdasarkan hasil penelitian Fardana dan Tairas (Amini, 2015: 12) menyimpulkan bahwa salah satu kendala yaitu keyakinan orang tua bahwa guru adalah pemegang otoritas pendidikan PAUD sehingga orang tua tidak perlu melibatkan diri mengkomunikasikan berbagai hal terkait dengan pendidikan anak. Selain itu, banyak kasus orang tua bekerja, namun masih mampu membagi waktu untuk anak-anak mereka. Sementara banyak pula orang tua yang tidak bekerja tetapi sulit sekali untuk berbagi waktu dengan anak-anaknya.

TK dan PAUD Assaabiq berada di J1. Bolorong No.175 Desa Cipakat kecamatan Singaparna Kabupaten Tasikmalaya. TK dan PAUD Assaabiq merupakan satu dari 4 sekolah tingkat taman kanak-kanak (Badan Pusat Statistik, 2016: 15) yang ada di Desa cipakat yang belum melaksanakan kegiatan parenting bagi orang tua siswa secara berkala dan terprogram terutama dalam hal manajemen materi parenting. Hal ini berakibat komunikasi antar sesama orang tua siswa dan antara orang tua siswa dengan guru maupun pengelola tidak terwujud secara optimal seperti yang diharapkan, sehingga pengasuhan anak di kelompok bermain dan di rumah mungkin tidak selaras.

Hasil penelitian Amini (2015: 17) menunjukkan bahwa sebagian orang tua masih bersikap overprotektif dalam mengasuh anak, serta menghendaki anaknya mendapatkan Pekerjaan Rumah (PR) dari guru TK-nya. Hal ini juga nampaknya muncul dari orang tua siswa di PAUD dan TK Assaabiq berdasarkan keterangan dari Kepala Sekolah. Kecederungan orang tua membandingkan anaknya dengan siswa yang lain. sebagian besar orang tua tidak sabar dalam melihat perkembangan kemajuan belajar anak, sehingga memaksakan anak untuk belajar dan menginginkan anaknya untuk "tidak main melulu" sehingga dipaksa untuk belajar agar pintar. Padahal, pada usia 4-6 tahun, tahap-tahap perkembangan anak masih didominasi oleh bermain. Indikasi lain, orang tua seringkali tidak sabar dalam mendidik anak-anaknya. Hal ini terlihat dari beberapa sikap orang tua yang seringkali memarahi anak atau menunjukkan sikap emosional tanpa mencari tahu terlebih dahulu alasan dari anak maupun keinginan anak yang sebenarnya. Istilah dalam bahasa sunda dikenal dengan istilah "haok polotot".

Indikasi tersebut menunjukkan bahwa orang tua belum memahami tahap-tahap perkembangan anak. Orang tua banyak yang tidak memahami bahwa pada usia dini, pembelajaran sebenarnya difokuskan pada perkembangan kognitif dan motorik melalui kegiatan bermain, bukan pendidikan formal seperti pada jenjang pendidikan yang lebih tinggi. Selain itu, masih banyak orang tua siswa yang terlihat kurang memberikan kemandirian bagi anakanaknya, serta terlalu membela berlebihan sehingga anak menjadi pengadu dan gagal menemukan solusi untuk masalah yang dihadapinya. Berdasarkan fakta tersebut, maka semestinya pengelola PAUD dan TK melakukan kolaborasi dengan orang tua, salah satunya membekali orang tua dengan berbagai pengetahuan mengenai tumbuh kembang anak, sehingga pola asuh anak di sekolah dan 
dirumah berjalan selaras. Hal ini yang mendasari pelaksanaan program Pengabdian Kepada Masyarakat (PKM) oleh tim PKM Universitas Muhammadiyah Tasikmalaya berupa program pembinaan parenting bagi orang tua siswa di PAUD dan TK Assaabiq dengan tema memahami fase tumbuh kembang anak yang meliputi materi mengenai pola asuh, menumbuhkan kemandirian anak dan kemampuan berpikir logis dan simbolik anak.

\section{BAHAN DAN METODE}

Pengabdian kepada masyarakat dilaksanakan pada hari Sabtu tanggal 6 Oktober 2017 bekerja sama dengan PAUD dan TK Assaabiq. Pengabdian kepada Masyarakat dengan judul Pembinaan Parenting bagi Orang Tua Siswa di PAUD DAN TK Assaabiq Singaparna Kabupaten Tasikmalaya ini bertema "Memahami Fase Tumbuh Kembang Anak", dengan menyajikan tiga materi yaitu Pola Asuh, menumbuhkan kemandirian anak, dan kemampuan berpikir logis dan simbolik anak.

\section{HASIL DAN PEMBAHASAN}

Kegiatan PKM dilaksanakan di PAUD dan TK Assaabiq selaku mitra. Secara geografis, sekolah ini berada di lingkungan Yayasan Assaabiq (Yayasan Pendidikan KH. Abdul Aziz) dimana dalam yayasan tersebut terdapat pesantren, PKBM (Pusat Kegiatan Belajar Mengajar), SMK, dan TK. Guru-guru yang ada di PAUD dan TK Assaabiq ini sudah sebagian besar merupakan lulusan pendidikan guru anak usia dini. Terdapat 5 orang guru secara keseluruhan, dengan jumlah siswa saat ini sebanyak 25 orang. Orang tua siswa sebagian besar berasal dari golongan ekonomi menengah kebawah. Karakteristik orang tua dengan ekonomi menengah ke bawah biasanya cenderung menekankan pada kualitas kepatuhan, kesopanan, kerapian dan kebersihan. Sedangkan pada status ekonomi tinggi lebih menekankan pada ciri-ciri psikologis pada anak seperti rasa ingin tahu, kebahagiaan, kemampuan mengarahkan diri sendiri, dan kematangan kognitif serta kematangan sosial (Amini, 2015: 18). Hal tersebut secara tidak langsung mendasari munculnya permasalahan mitra seperti yang diuraikan.

Tujuan kegiatan PKM yaitu memberikan edukasi mengenai tumbuh kembang anak, sehingga diharapakan terjadi keselarasan pengasuhan anak di sekolah dan di rumah seiring dengan pemahaman orang tua terhadap fase tumbuh kembang anak. Selain itu, memberikan pengertian kepada orang tua bahwa tanggung jawab dalam keberhasilan pendidikan anak bukan sepenuhnya menjadi tanggung jawab guru di sekolah, tetapi dipengaruhi oleh andil orang tua. Gaya pengasuhan yang dilakukan oleh orang tua, berpengaruh secara langsung terhadap kematangan emosi, fisik dan karakter anak. Oleh karena itu, penting bagi orang tua untuk memahami dan mengerti bagaimana seharusnya kegiatan pengasuhan anak dilakukan sehingga mendukung terhadap prestasi belajar anak. Hal ini diungkapkan dalam hasil penelitian Jeynes tahun 2003 (Hornby, 2011: 1) yang menunjukkan bukti bahwa keterlibatan orang tua efektif dalam memfasilitasi prestasi akademik yang diperoleh oleh anak. Bentuk keterlibatan orang tua yang dimaksud oleh Jeynes (Hornby, 2011: 1) misalnya menyimak anak-anak membaca, atau memeriksa pekerjaan rumahnya. Termasuk juga menghadiri workshop dan seminar pendidikan bagi orang tua.

Program parenting merupakan bentuk kegiatan informal yang dilakukan untuk menyelaraskan kegiatan-kegiatan pengasuhan dan pendidikan anak di kelompok bermain dan di rumah (Hariawan, 2011: 1). Selama ini kegiatan yang telah dilakukan untuk pendekatan dengan orang tua di PAUD dan TK Assaabiq berupa kegiatan rapat orang tua khususnya berkaitan dengan informasi kedinasan, yang diselingi dengan kegiatan makan bersama orang tua, siswa dan guru. Pengertian bagaimana pola asuh dan pola pendidikan anak disampaikan pihak sekolah melalui kegiatan nonformal saja dan belum terstruktur, sehingga masih banyak orang tua yang kurang memahami bagaimana fase tumbuh kembang anak. Oleh karena itu, fokus kegiatan PKM berupa pembinaan parenting bagi orang tua siswa di PAUD dan TK Assaabiq ini meliputi pemberian materi mengenai pola asuh, menumbuhkan kemandirian anak, dan kemampuan berpikir logis dan simbolik anak.

Materi pola asuh difokuskan pada penyebab, cara mengidentifikasi dan tindakan apa yang dapat dilakukan oleh orang tua ketika anak mengalami temper tantrum, pasif dan berbohong. Temper tantrum yaitu ledakan emosi anak-anak dalam kesulitan emosional, ditandai dengan sikap 
keras kepala, menangis, menjerit, berteriak, menjerit-jerit, pembangkangan, mengomel marah dan kekerasan. Selanjutnya, anak pasif yang dimaksud yaitu anak yang menerima saja, anak cenderung lebih pendiam dibanding anak kebanyakan, anak tersebut juga tidak menyukai suatu kelompok dan lebih suka sendiri. Sedangkan untuk gejala anak berbohong dapat diamati mulai usia 3 tahun dan menginjak 4 tahun. Penyebab anak berbohong, karena anak mempunyai kemampuan berfikir terbalik termasuk pada hal-hal yang abstrak. Selain itu, anak belum bisa membedakan antara fantasi dan kenyataan. Tujuan diberikannya materi mengenai pola asuh untuk memberikan pengetahuan bagi orang tua mengenai perkembangan anak usia 2-6 tahun secara psikologis. Setelah orang tua memahami fase tumbuh kembang anak dan mengetahui pola asuh yang tepat, diharapkan pola komunikasi antara orang tua dan anak akan terjalin dengan baik. Lebih lanjut, pengetahuan tersebut dapat memberikan kontribusi positif terhadap perkembangan prestasi dan psikologi anak, sehingga terjadi keselarasan antara pengasuhan orang tua dan pola pendidikan di sekolah.

Materi selanjutnya yaitu menumbuhkan kemandirian anak. Kemandirian itu sendiri yaitu melakukan sesuatu atas dasar motivasi sendiri. Adapun cara- cara menumbuhkan kemandirian anak yang menjadi materi pembinaan yaitu:

1. Menjadi role model bagi anak, misalnya saat anak beranjak ke usianya yang pertama, ia senang seklai meniru.

2. Melakukan pembiasaan dan pengulangan, caranya adalah dengan menciptakan rutinitas, karena membantu anak merasa bisa melakukan sesuatu karena sudah terbiasa.

3. Membuat pilihan yang mengandung penjelasan, dengan membuat pilihan sendiri anak akan merasa dihargai sehingga menimbulkan kepercayaan dirinya bertumbuh. Namun perlu diberikan penjelasan oleh orang tua, mengenai konsekuensi dari pilihan yang dibuat oleh mereka sendiri. Bantu anak memahami bahwa ketika ia memilih sesuatu, maka ia kehilangan yang lain.

4. Mengajukan permintaan, pada saat usia 1 tahun, anak sudah mulai bisa mendapatkan tugas sederhana. Misalnya meminta anak untuk membuang bungkus kue ke tempat sampah, jangan lupa memberikan pujian jika anak melakukannya dengan baik.

5. Memberikan kesempatan, misalnya menggosok gigi sendiri, menyisir rambut sendiri, atau kegiatan lain sesuai dengan usianya yang ingin dilakukan oleh anak sendiri.

Pemberian materi ini bertujuan agar orang tua memahami dan mampu membedakan perlakuan pengasuhan mana yang dapat melatih kemandirian anak, serta pengasuhan mana yang dapat memanjakan anak sehingga kemandiriannya tidak berkembang optimal dan berpengaruh terhadap kemampuan anak menyelesaikan masalah, kemampuan sosial, dan religiusitas anak.

Materi ketiga mengenai kemampuan berpikir logis dan simbolik pada anak. Materi ini berisi tentang tahapan perkembangan kognitif anak usia 2-6 tahun. Salah satu kemampuan kognitif yang diharapkan berkembang optimal melalui jalur pendidikan PAUD dan TK yaitu kemampuan berpikir logis dan simbolik anak. Hal ini didasarkan pada tahapan perkembangan kognitif anak menurut Piaget, bahwa anak usia 2-6 tahun berada pada tahap perkembangan preoperational (sebelum tahap operasional) (Schunk, 2012: 237). Tahap ini terdapat dua periode, yaitu periode prekonseptual (usia 2-4 tahun) dan periode intuitif (usia 4-6 tahun), dimana anak mulai menggunakan simbol, berfikir imajinatif, dan perkembangan bahasa yang cepat. Kemampuan berpikir logis yang dimaksud diantaranya yaitu kemampuan anak dalam membedakan, mengklasifikasikan, dan memahami pola. Sedangkan kemampuan simbolik yaitu kemampuan anak membayangkan secara mental suatu objek yang tidak ada, atau merepresentasikan objek yang ada dalam imajinasinya baik menggunakan kata-kata maupun gambar. Kemampuan simbolik yang dimaksud dalam PAUD dan TK diantaranya mengenal, menyebutkan dan menggunakan konsep bilangan, mengenal huruf, serta mampu merepresentasikan berbagai benda dan imajinasinya dalam bentuk gambar (IES, 2013).

Tujuan diberikannya materi ini yaitu sebagai upaya memberikan pengetahuan kepada orang tua mengenai perkembangan kognitif anak khususnya kemampuan logis dan simbolik. Informasi tersebut dapat membantu orang tua memahami bagaimana upaya yang dapat 
dilakukan untuk membantu mengembangkan kemampuan kognitif anak melalui aktifitas seharihari. Selain itu, memberikan pemahaman kepada orang tua bahwa matematika dapat diajarkan sejak dini, melalui lingkungan alami anak dalam upaya meningkatkan kemampuan berpikir logis dan simbolik anak.

Selanjutnya kegiatan PKM dilanjutkan dengan refleksi orang tua siswa. Pada sesi ini, orang tua diminta untuk mengidentifikasi masalah- masalah anak yang selama ini dihadapi, kemudian berbagi cara bagaimana selama ini mengatasinya. Kemudian solusi tersebut dievaluasi apakah sudah tepat atau belum secara bersama-sama dalam forum diskusi. Bagi yang belum memiliki solusi, diminta untuk menuliskan solusi apa yang dianggap tepat. Beberapa hasil refleksi orang tua siswa yaitu:

Anak saya punya sifat agak pemarah, kadang-kadang keinginan anak harus selalu dituruti. Saya suka bingung harus bagaimana, karena di rumah suami tidak ada karena bekerja di luar kota. Saya ingin sekali bertukar pendapat dengan anak-anak tapi susah. Hingga akhirnya saya seringkali menuruti kemauan anak daripada anak marah-marah (ngamuk).

Anak saya usia 4 tahun, ketika melakukan sesuatu inginnya instan sehingga akhirnya selalu menyuruh ibu untuk mengerjakannya.

Hasil refleksi menunjukkan sebagian besar orang tua sebelumnya tidak sabaran menghadapi anak. Seringkali anak langsung dimarahi dan dihukum, karena perasaan malu oleh orang lain karena anak mengangis terus. Namun ada juga orang tua yang selalu menuruti kemauan anak, yang penting anak diam dan tidak menangis. Hal ini bukan solusi tepat untuk menagatasi hal tersebut, karena jika anak diberikan perlakuan yang keras, akan menyebabkan trauma secara psikologis. Namun, terlalu lembut juga dapat menyebabkan anak tidak jera, artinya anak akan belajar jika ingin sesuatu maka apa yang harus dilakukan adalah mengangis atau mengamuk.

Selain itu, kesulitan untuk melepaskan perasaan tidak tega kepada anak atau tidak sabaran sehingga terus langsung membantu anak dalam aktifitasnya. Selama ini, ketika anak melakukan aktifitas selalu dibantu ibu, dan segala kebutuhannya dilayani. Selain itu, ketidaksabaran dari ibu, karena alasan daripada anak menangis atau rewel, langsung ikut mengambil alih kegiatan dengan membantu anak, tidak memberikan kesempatan kepada anak untuk menyelesaikan pekerjaannya sendiri. Sikap demikian menyebabkan kecenderungan kemandirian anak tidak tumbuh secara optimal. Keterangan dari orang tua dan guru berkaitan dengan kemampuan kognitif, orang tua cenderung tidak sabar dalam melihat perkembangan anak. Keinginan orang tua agar anak mampu menulis, membaca dan berhitung secara cepat. Padahal, bagi anak di PAUD dan TK, bermain merupakan cara anak belajar, adapun materi yang diiberikan berupa stimulus untuk mempersiapkan anak pada jenjang pendidikan selanjutnya. Hal tersebut karena kurangnya pemahaman terhadap bagiamana fase tumbuh kembang anak baik dari aspek kognitif, afektif maupun psikomotor anak.

Namun, pada tahap evaluasi hasil refleksi, sebagian besar orang tua sudah mampu mengidentifikasi fase tumbuh kembang anak setelah diberikan materi. Bahkan beberapa diantaranya mampu memberikan solusi yang tepat. Misalnya seperti hasil evaluasi salah satu orang tua yaitu,

Waktu sekolah anak saya sedikit pendiam, tertutup dan cuek. Solusi: mengajak anak bicara, supaya anak bisa bercerita atas apa yang sudah dilewati di sekolah.

Keberlanjutan pengabdian kepada masyarakat di PAUD dan TK Assaabiq, yaitu dengan mengadakan pertemuan dengan orang tua setiap bulan dibawah koordinasi kepala sekolah dan guru. Adapun materi yang dibahas tidak hanya informasi yang sifatnya kedinasan, namun juga membahas mengenai tumbuh kembang anak dan pola pendidikan bagi anak. Hasil evaluasi pada sesi terakhir pada kegiatan PKM, ditindaklanjuti dengan membuat buletin berisi jawaban terhadap pertanyaan orang tua mengenai masalah-masalah yang dihadapi oleh anak. Buletin tersebut akan 
ditempelkan di mading atau papan informasi di PAUD dan TK Assaabiq, sehingga setiap orang tua dapat membacanya.

\section{KESIMPULAN DAN SARAN}

Program parenting bagi orang tua siswa di PAUD dan TK Assaabiq Singaparna Kabupaten Tasikmalaya ini sebagai kegiatan pengabdian kepada masyarakat dilaksanakan dengan tujuan memberikan pemahaman mengenai fase tumbuh kembang anak bagi orang tua. Adapun materi yang diberikan yaitu pola asuh, menumbuhkan kemandirian anak, dan kemampuan berpikir logis dan simbolik anak. Pengabdian masyarakat ini bekerja sama dengan PAUD dan TK Assaabiq yang berada di lingkungan Yayasan Assaabiq (Yayasan Pendidikan KH. Abdul Aziz). Keberlanjutan program pengabdian kepada masyarakat yaitu dengan mengadakan pertemuan dengan orang tua setiap bulan dibawah koordinasi kepala sekolah dan guru. Adapun materi yang dibahas tidak hanya informasi yang sifatnya kedinasan, namun juga membahas mengenai tumbuh kembang anak dan pola pendidikan bagi anak. Selain itu, ditindaklanjuti dengan membuat buletin berisi jawaban terhadap pertanyaan orang tua mengenai masalah-masalah yang dihadapi oleh anak. Buletin tersebut akan ditempelkan di mading atau papan informasi di PAUD dan TK Assaabiq, sehingga setiap orang tua dapat membacanya.

\section{UCAPAN TERIMA KASIH}

Ucapan terimakasih penulis sampaikan kepada Universitas Muhammadiyah Tasikmalaya yang telah memberikan dana untuk melaksanakan kegiatan Pengabdian Kepada Masyarakat. Secara khusus ucapan terimakasih penulis sampaikan kepada 1) Rektor Universitas Muhammadiyah Tasikmalaya, 2) Ketua Lembaga Penelitian dan Pengabdian Masyarakat (LPPM) Universitas Muhammadiyah Tasikmalaya (Mujiarto, S.T., M.T.), 3) Kepala sekolah PAUD dan TK Assaabiq Singaparna Kabupaten Tasikmalaya (Drs. Nunung Nurhasnawati, S.Pd.Aud.), dan 4) Guru dan orang tua siswa PAUD dan TK Assaabiq Singaparna Kabupaten Tasikmalaya.

\section{DAFTAR PUSTAKA}

Amini, M. (2015). Profil keterlibatan orang tua dalam pendidikan anak usia dini. Jurnal ilmiah VISI PPTK PAUDNI, Vol 10 No.1, juni 2015.

Badan Pusat Statistik. (2016). Kecamatan Singaparna dalam Angka 2016. Tasikmalaya: Badan Pusat Statistik.

IES. (2013). Teaching math to young children. Washington, DC: NCEE, Institute of education science

Hariawan, R. (2011). Manajemen program parenting pada PAUD unggulan nasional (studi multi situs pada PAUD anak saleh dan PAUD firdaus di Malang Raya). Tesis Program Studi Manajemen Pendidikan, Program pascasarjana Universitas Negeri Malang.

Hornby, G. (2011). Parental involvement in childhood education. London: Springer.

Kemdikbud. (2014). Standar nasional pendidikan anak usia dini. Jakarta: Kemdikbud.

Morrison, G.S. (2004). Early childhood education today ( $9^{\text {th }}$ ). New Jersey: Pearson Education, Inc.

Schunk, Dale H. (2012). Learning theories: an educational perspective. Boston: Pearson. 


\section{LAMPIRAN}
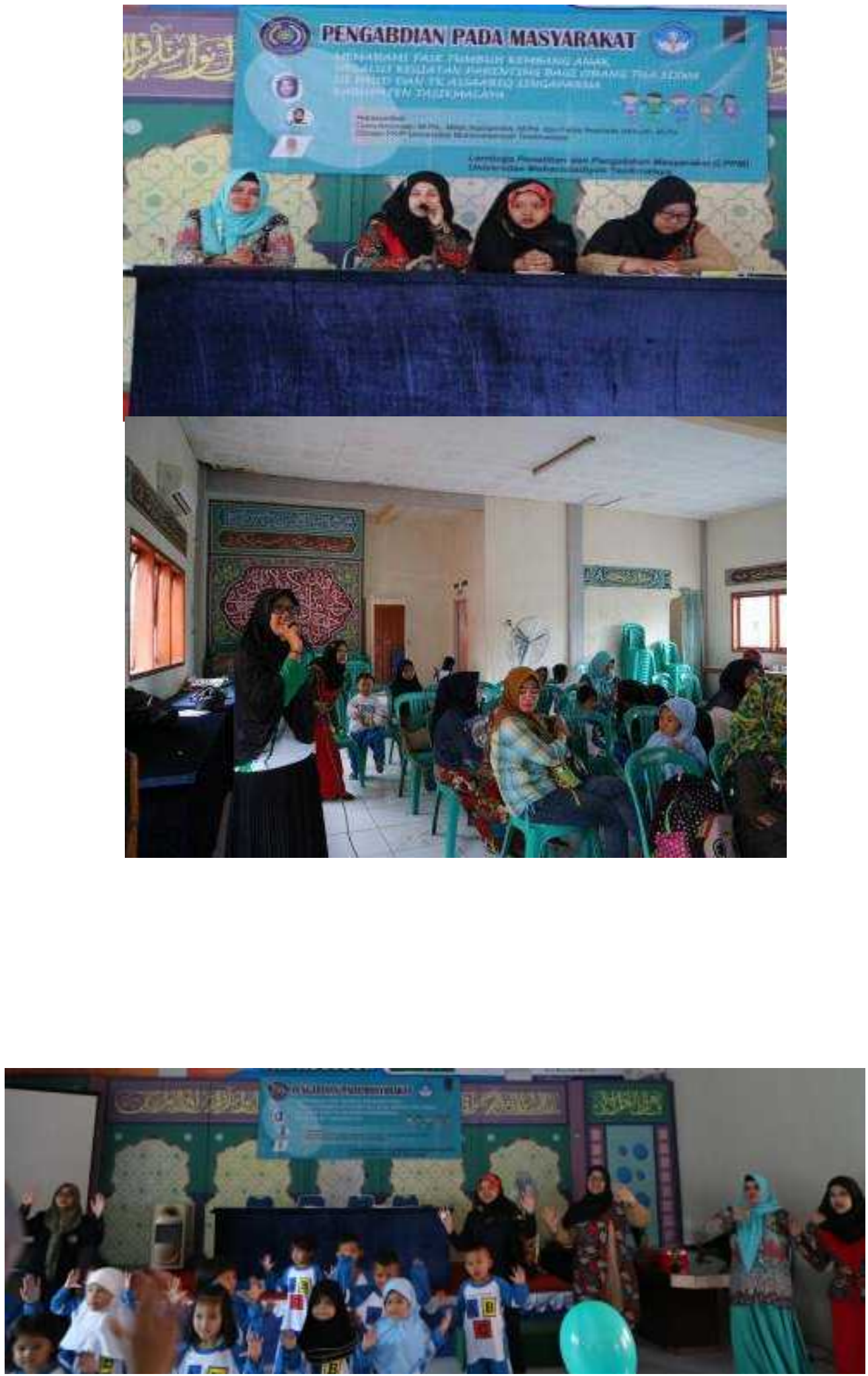

Sumber: Arumsari, Nurkamilah dan Isti'adah (2017: 20)

Gambar 3. Sesi Games 


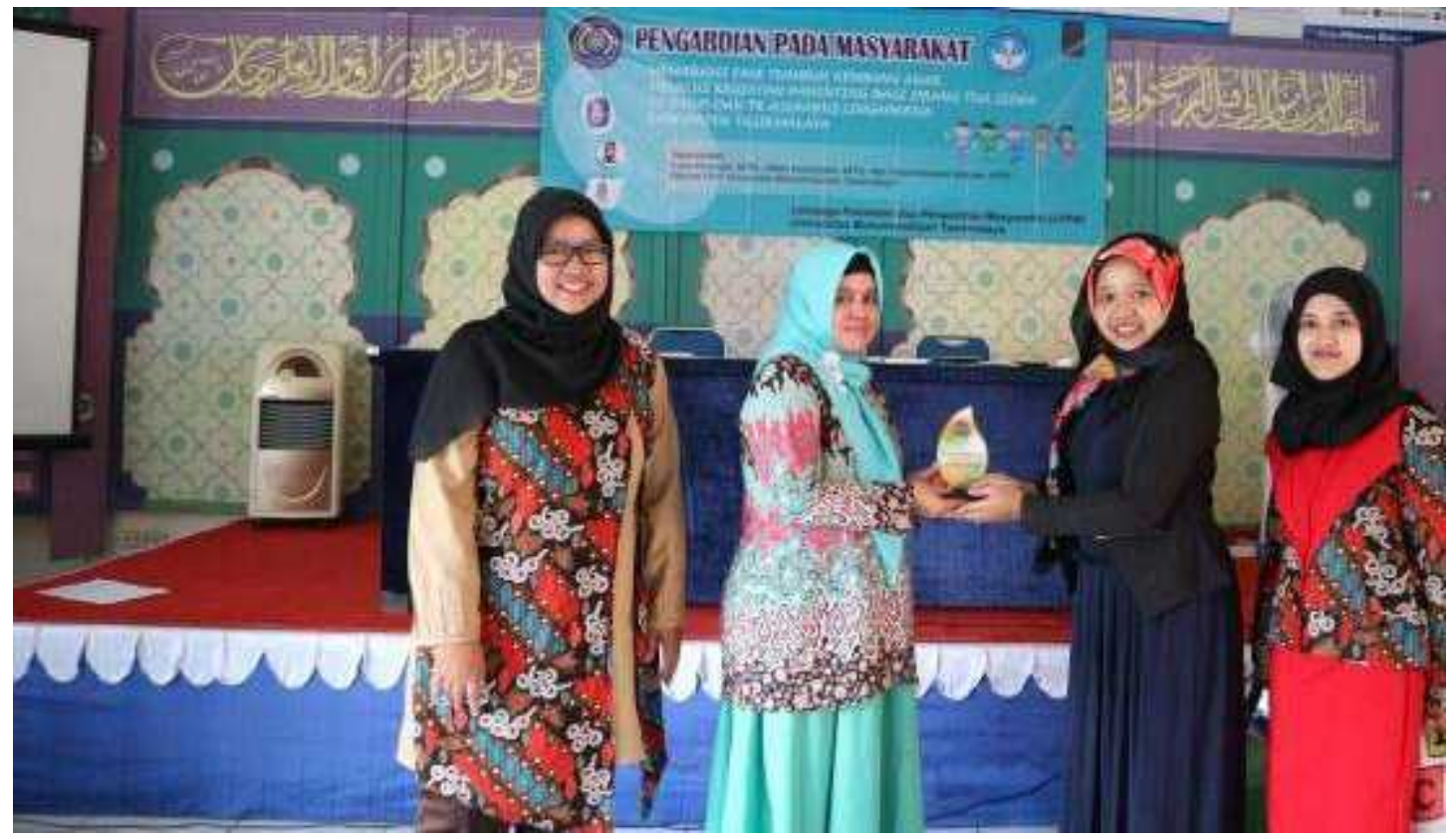

Sumber: Arumsari, Nurkamilah dan Isti'adah (2017: 20)

Gambar 4. Pemberian Cinderamata

Hama wali Mafisah Istamiafi

Name anak: Mamira Ramadhania

Masalah

1. Waktu disekolah sedikit pendiam

\section{Tertutup \\ 3. cuek}

cara yang suclah dilakukan.

1. Mungajak nyobrol dengan anak, supaya anak bisa bercerita atas apa yang
sudah dilewatinya disekulab

Sumber: Arumsari, Nurkamilah dan Isti'adah (2017: 27)

Gambar 5. Hasil Refleksi Oorang tua 


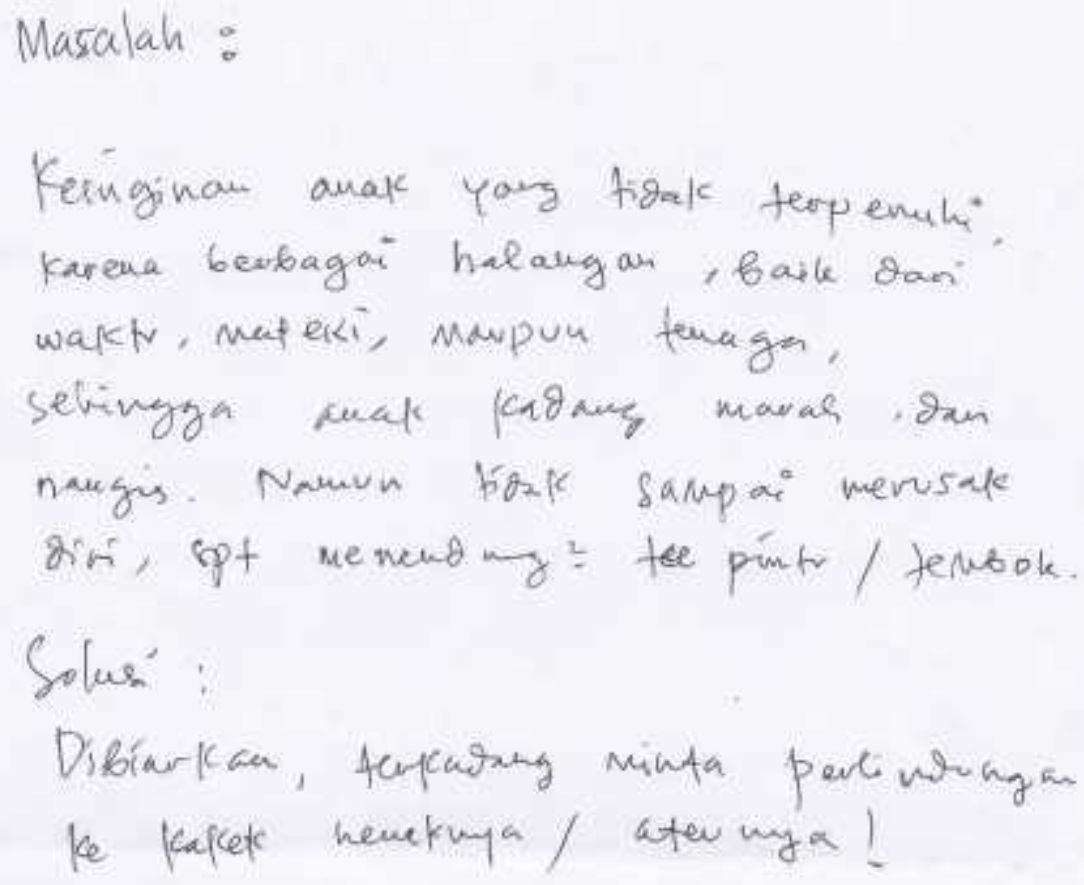

Sumber: Arumsari, Nurkamilah dan Isti'adah (2017: 28)

Gambar 5. Hasil Refleksi Oorang tua 